\title{
Foodborne Group-G Streptococcal Pharyngitis Outbreak Among Hospital
}

\author{
Hastane Personelinde Ortaya Çıkan Gıda Kaynaklı Bir G Grubu Streptokok Faranjiti Salgını \\ Nihal Karabiber ${ }^{1}$, Zeynep Ceren Karahan², Ebru Aykut Arca³, Alper Tekeli4
}

1Training and Research Hospital, Turkey

Traning and Research Hospital Turky 2Ankara University, Faculty of Medicine, Department of Medical Microbiology

Aning and Research Hospital, Turkey

University, Faculty of Medicine, Department of Medical Microbiology

\begin{abstract}
In January,2004 an explosive epidemic of pharyngitis occured among the staff working atIntensive Care Units and Operation Rooms of Türkiye Yüksek Ihtisas Teaching Hospital, The symptoms were indistinguishable from those of group A streptococcal pharyngitis. Sore throat and weakness were the prominent symptoms in ( $91 \%$ and $87 \%$, of patients respectively). In a two-day period, throat cultures were taken from 377 personnel and 121 (32\%) of them were found to be positive for group-G beta-hemolytic streptococci. The configuration of the epidemic curve suggested a common source of exposure. Respiratory spread of streptococci in such a rapid fashion would be unlikely. Sixteen of the 121 positive throat cultures were obtained from the staff of the catering firm which provided the food services for the hospital staff. Most of these catering firm personnel were serving the departments where the epidemic occured. With these data, the outbreak was considered to be foodborne. PFGE analysis of randomly selected 40 (including the 16 strains isolated from the catering firm personnel) strains showed only one digestion pattern. Prompt treatment with penicillin was given to all the sick personnel and a 9-day religious holiday approaching consequently terminated the outbreak. Control cultures were negative for all the subjects.

Key Words: Group G Shreptococci, outbreak, PFGE

Ankara Türkiye Yüksek Ihtisas Eğitim ve Araștırma Hastanesi Yoğun Bakım Kliniklerinde ve Ameliyathanelerinde çalıșan personel arasında Ocak 2004'de bir farenjit salgını gelișmiștir. Hastaların semptomları A grubu streptokok farenjiti bulgularıla örtüșmekte olup, hastaların \%91'inde boğaz ağrısı, \%87'sinde ise genel halsizlik izlenmiștir. İki gün içerisinde 377 personelden boğaz kültürü alınmıș, bu hastaların $121^{\prime}$ inin (\%32) kültüründe G-grubu beta hemolitik streptokok üremiștir. Salgın eğrisi incelendiğinde, streptokokların solunum yolu ile bu șekilde hızla yayılması mümkün olmadığı, bu hastaların aynı enfeksiyon kaynağına maruz kaldıkları düșünülmüștür. 121 pozitif kültür örneğinin 16'sının, salgının ortaya çıktığı kliniklere hastane personeli yemeklerini dağıtan yemek firması elemanlarına ait olduğunun anlașılması üzerine, salgının gıda kaynaklı olduğu düșünülmüștür. Yemek firması personelinden izole edilen 16 örnek dahil olmak üzere, rastgele seçilen 40 örneğin PFGE analizi sonuçları, tek bir kesim paternini ortaya koymuștur. Tüm hastalanan personele penisilin tedavisi bașlanmıș, salgını takiben bașlayan dokuz günlük bayram tatili esnasında salgın sona ermiș, kontrol kültürlerinde üreme gözlenmemiștir.
\end{abstract}

Anahtar Sözcükler: G grubu streptokok, salgın, PFGE

Foodborne outbreak of streptococcal pharyngitis is relatively rarely reported. While group-A streptococci (GAS) are the main causative agents of such outbreaks (1-6), a few epidemics caused by group-G streptococci (GGS) have been published (7-9). Here we describe a foodborne outbreak of group-G streptococcal pharyngitis occured among the staff of a teaching hospital in Ankara.

\section{METHODS}

The first day of the outbreak:

On 29th January 2004, 111 hospital personnel attended to the microbiology laboratory with complaints of pharyngitis and had their throat culture obtained. The most striking symptoms were intensive weakness and sore throat with difficulty in swallowing. Most of these personel were working in the cardiovascular surgery intensive care 
unit (CVS-ICU), gastrointestinal surgery intensive care unit (GIS-ICU) and their operation theatres, catheter laboratory and anesthesia and reanimation clinic.

\section{The second day of the outbreak:}

On $30^{\text {th }}$ January 2004, beta-hemolytic streptococci (BHS) were isolated from 65 of 111 (59\%) personnel whose throat cultures were obtained on the first day. Except for one isolate obtained from a personel working for the catering firm, all of the isolates, except one, were Lpyrrolidonyl- $\beta$-naphtylamide (PYR)negative.

Isolation of $\mathrm{BHS}$ in such a high rate in one day suggested that there might be an outbreak. After realizing that three of the 65 throat culture-positive personnel were among the waiters serving at the departments where the outbreak occured and the fact that those staff were from the catering firm which provided all the food services for the hospital, we thought that the outbreak might have been foodborne.

On the same day, an additional 219 health care workers (i.e. doctors, nurses, and technicians) attended to the microbiology laboratory for throat culture. At the same time, 47 staff (waiters, cooks etc.) working for the catering firm were screened for any lesions on their hands, and their throat cultures were obtained. Prompt treatment with penicillin was given to all the symptomatic personnel (both working at the hospital and the catering firm). As the incubation period for this type of outbreak was generally considered to be about two days $(1,2,6)$, the menu of January 27 was examined and seen that roast, pureé (mashed potatoes) and cream chocolate were served for hospital staff that day. Considering that some previous streptococcal pharyngitis outbreaks had occured by milk consumption (1), we attempted to learn where the catering firm supplied their milk and milk products from. We interviewed with the manager of the dairy product plant the catering firm was dealing with and planned to obtain screening throat cultures from their staff.

In order to prepare a case definition chart, a questionnaire form was prepared and all the personnel affected from the outbreak were asked to fill it out.

\section{The third day of the outbreak:}

On $31^{\text {st }}$ January 2004, BHS were isolated from 45 of $219(21 \%)$ health care personnel and from 14 of $47(30 \%)$ catering firm personel whose cultures were obtained the day before. Two of the health care personnel isolates were PYR-positive, the rest were again PYR-negative.

All of the 124 BHS strains isolated in these two days were tested for bacitracin (BA) and trimethoprim/sulfamethoxazole (TMP/SMZ) susceptibilities. Group antisera for streptococci were ordered in order to define the groups of the isolates.

All the strains were subcultured and cryopreserved for definite group typing, antibiotic susceptibility testing, and future genotyping due to a 9-day religious holiday approaching the day after.

Follow up cultures were obtained one week after the end of antibiotic treatment.

\section{PFGE genotyping}

PFGE typing of the outbreak strains was performed at the Microbiology and Clinical Microbiology Department of Ankara University Faculty of Medicine in January, 2006. DNA was extracted from the subcultures made from the stock cultures of 41 randomly selected strains of GGS. Special attention was given for including at least one representative isolate obtained from each division participating in the outbreak. SmaI digestion of the DNA samples was performed according to the method decribed by Bert et al. (10). Fragments were seperated at $200 \mathrm{~V}(6 \mathrm{~V} / \mathrm{cm})$ with CHEF DR II apparatus (Bio-
Rad Laboratories, Hercules, USA) with pulse times 5 to $15 \mathrm{~s}$ for 12 hours and 1 to $45 \mathrm{~s}$ for 12 hours at $14^{\circ} \mathrm{C}$. Lambda ladder N034OS (New England Biolabs - Hertfordshire, UK) was used as molecular size marker. After electrophoresis, the gel was stained with ethidium bromide for 20 minutes and was washed with distilled water and photographed under UV light. Interpretation of the grouped PFGE patterns was performed according to the guidelines of Tenover et al. (11).

\section{RESULTS}

A total of 377 throat cultures were evaluated in a two-day period and 124 BHS strains were isolated. Presumptive identification with the PYR test, and bacitracin and trimethoprim/sulfametoxazole disk diffusion tests showed that 3 strains were GAS, while 121 strains were non group-A. In definite grouping by Streptococcus Grouping Kit (Avipath-Strep,OMEGA), these 121 strains were found to be GGS and 3 strains were GAS. One of the GAS strains was isolated from a catering personnel on the first day while the other two were isolated from health care personnel on the second day. During the outbreak, 16 of the GGS were isolated from 50 catering firm personnel (32\%). Throat cultures obtained from dairy product plant personnel were all negative for GAS or GGS. All the BHS were found to be sensitive to penicilin $G$ and erythromycin by agar disc diffusion method. Culture positive hospital staff and their departments are shown in table 1 .

SmaI digestion and PFGE analysis of randomly selected 41 strains yielded 10 bands ranging from $30-750 \mathrm{~kb}$ (Figure 1). All of the 41 isolates grouped in one major pulsotype according to the criteria of Tenover et al. (11). Clonal analysis of the strains was performed by using Gene Directory software, and a similarity coefficient of $>80$ was found among the strains. All the isolates showed an epidemiological link which was the 
representative of an outbreak with minimal genetic diversity.

The questions in the questionnaire form were answered by 141 affected people. Of these 141, 64 were GGS positive, 19 had normal throat flora.

Table 1. Departments of GGS positive personel

\begin{tabular}{|l|c|c|c|c|}
\hline \multirow{2}{*}{ Department } & \multicolumn{2}{|c|}{ The first day } & \multicolumn{2}{c|}{ The second day } \\
\cline { 2 - 5 } & $\mathbf{n}$ & $\mathbf{\%}$ & $\mathbf{n}$ & $\mathbf{\%}$ \\
\hline CVS ICU* & 39 & 60 & $19(2)$ & 32 \\
\hline GIS ICU** & 19 & 29 & 7 & 12 \\
\hline Catering Firm & $3(1)$ & 5 & 14 & 24 \\
\hline Cardiology ICU & 0 & 0 & 6 & 10 \\
\hline Catheter Laboratory & 2 & 3 & 5 & 8 \\
\hline Other & 2 & 3 & 8 & 14 \\
\hline Total & 65 & 100 & 59 & 100 \\
\hline
\end{tabular}

*Cardiovascular Surgery Intensive Care Unit

**Gastrointestinal Surgery Intensive Care Unit

(Numbers in bracelets belong to GAS isolates)

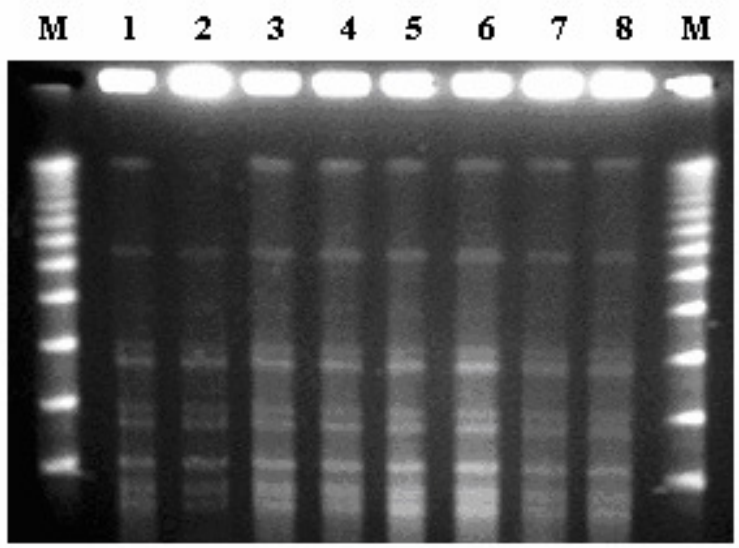

Fig 1. PFGE patterns of $S m a \mathrm{I}$ digests of group G isolates.

M: Lambda ladder. Lanes 2-9: PFGE patterns of selected isolates

Table 2. The frequency of symptoms according to answers given to the questionnaire of 64 GGS positive personel

\begin{tabular}{|l|c|c|}
\hline \multicolumn{1}{|c|}{ Symptoms } & $\mathbf{n}$ & $\mathbf{\%}$ \\
\hline Sore throat & 58 & 91 \\
\hline Weakness & 56 & 87 \\
\hline Difficulty in swallowing & 51 & 80 \\
\hline Fever & 42 & 66 \\
\hline Chilling & 39 & 61 \\
\hline Nauseae & 19 & 30 \\
\hline Cough & 16 & 25 \\
\hline Abdominal pain & 9 & 14 \\
\hline Vomiting & 7 & 11 \\
\hline Joint pain & 2 & 3 \\
\hline Muscle pain & 1 & 1.5 \\
\hline
\end{tabular}

symptoms, with $91 \%$ and $87 \%$ in frequencies, respectively.

During the outbreak, 121 GGS were isolated from 377 throat cultures in two days (32\%). Before this outbreak, GGS hadn't been isolated from anyone working at the hospital.

Prompt treatment with penicillin to all culture-positive personnel and the 9day religious holiday approaching consequently terminated the outbreak. All the follow-up throat cultures of the affected personnel were negative for GGS.

\section{DISCUSSION}

The outbreak reported here is the first from Turkey caused by GGS. No food could be incriminated for transmission but 16 culture positive catering firm personnel and the explosive beginning suggested that it might have been foodborne.

In this hospital, a catering firm provides all the food services. There is a main dining room in which 900 hospital personnel have their lunch. In other smaller dining rooms belonging to the departments of CVS ICU, GIS ICU, Catheter Laboratory, Cardiology ICU, Radiology and Dialysis; 150, 120, 55, 35, 35 and 20 personnel have their meal, respectively. The outbreak begun explosively among the hospital personnel who had their meal at the dining rooms in the CVS ICU and GIS ICU (58 and 26 personnel, respectively) departments.

The fact that $30 \%$ of the catering firm personnel were positive for GGS on their throats and that the most health care personnel affected from the outbreak had their meal at the dining rooms where those firm staff were working and the high attack rate in a short time suggested that this outbreak might have been foodborne.

Strayker et al. (9) reported a group-G straeptococcal pharyngitis outbreak occured among the people who 
attended a convention held in a Florida hotel in June 21-24, 1979. Seventy-two $(31 \%)$ of 231 interviewed conventioneers were ill. GGS were isolated from the throats of $10(63 \%)$ of 16 people with pharyngitis. All people who attended the louncheon and got sick had had a chicken salad served at the louncheon. In this outbreak, five cooks helped to prepare the luncheon foods, one of whom who had prepared the main portion of the chicken salad served at the June 22 luncheon, had an onset of pharyngitis on June 23 and her throat culture yielded GGS. Streptococci were not isolated from the culture of the chicken salad; however the culture plates were overgrown vith a variety of organisms. How the chicken salad might have become contaminated with GGS was unclear. The authors concluded that a respiratory carrier could have inoculated the food by sneezing and expelling streptococci in droplets or by touching the food with hands contaminated by respiratory secretions (9).

In another group-G streptococcal pharyngitis outbreak occured in a college in the USA egg salad was the incriminated food, and the same organism had been isolated from a food handler's pharynx at the peak of the epidemic. This food handler assisted shelling the eggs and mixing the salad. In both foodborne outbreaks, the causative agent couldn't have been isolated from the food, but had been supported by epidemiological data (8).

Cohen et al. (7) had reported another group-G streptococcal foodborne outbreak in an Israeli Military Base. Thirty-two $(84 \%)$ of the throat cultures taken from 37 patients yielded GGS and 6 of the 28 foodhandlers had positive cultures of the same group. The organism was also isolated from one food sample (7).
The common properties of foodborne streptococcal pharyngitis are explosive beginning, abrupt onset of clinical symptoms, a two-day incubation period and the configuration of the epidemiologic curve $(1,3,4,8,9)$. In our outbreak it was impossible to determine the incubation period because there was no person or no food incriminated definitely. However, it was similar with the other outbreaks caused by GGS as of explosive occurence, course, clinical symptoms and response to treatment of penicillin (79).

It is well known that patients with acute streptococcal pharyngitis harbour extensive amount of causative agents in their throats and noses (10). Cooks and waiters who yielded GGS in their throat culture during the outbreak might have contaminated the foods by their respiratory secretions or droplets .

The configuration of the epidemic curve suggested a common source of exposure. Since respiratory spread of streptococci in such a rapid fashion would be highly unlikely and that 16 of 121 positive throat cultures were from the staff of the catering firm which provided all the food services for the hospital, and that most of them were working at the departments in which the outbreak occured, we considered that the outbreak might have been foodborne. The symptoms of group$G$ streptococcal pharyngitis were indistingnishable from those of GAS pharyngitis in this outbreak. Sore throat and weakness were the prominent symptoms.

In the outbreak presented here many culture positive cooks and waiters were ill just before or during the explosion of the outbreak. There probably may have been only one ill person (probably cook) who then transmitted the infection to other cooks and waiters. It is possible that more than one GGS positive person contaminated the foods.

There was 19 symptomatic personnel whose throat cultures yielded normal flora during this outbreak, who were considered to be of viral ethiology.

In this outbreak the rate of secondary transmission could not be determined because of the nine-day holiday approaching right after the outbreak. All the culture-positive patients were given penicillin and all of them healed completely. No streptococcal sequelae developed among the personnel affected from the outbreak, a result also noted in a description of another group-G streptococcal pharyngitis outbreak (8).

There is only one reported foodborne streptococcal outbreak from Turkey occured in 1988. In this outbreak, explosive pharyngitis epidemics due to GAS occured among the staff of an institution in Ankara, following a lunch. Epidemiological investigation indicated that the outbreak might have been foodborne. Although causative organism hasn't been isolated from any food, a salad prepared with bean and boiled egg was considered as the vehicle of transmission. GAS were isolated from the throats of $37(63.8 \%)$ of 58 persons with pharyngitis at that outbreak (6).

As far as we know, this is the only group-G streptococcal pharyngitis outbreak reported from Turkey. Although we could not obtain any food samples, the explosive nature of the outbreak and identification of possible sources for infection made us consider this outbreak to be foodborne. Our purpose was to evaluate the clinical symptoms and other characteristics of the outbreak, and share our experiences of this rare kind of outbreak with professonal colleagues. 


\section{REFERENCES}

1. Levy M, Johnson CG, Kraa E. Tonsillopharyngitis caused by food-borne group A streptococcus: A prison based outbreak. Clin. Infect. Dis. 2003; 36: 175-182.

2. Semesh E, Fischel T, Goldstein N, Aklan M, Livneh A. An outbreak of food-borne streptococcal throat infection. Isr. J. Med. Sci. 1994; 30: 275-278.

3. Claesson BEB, Svenson NG, Goddhardsson L Garden B. A foodborne outbreak of group A streptococcal disease at a birthday party. Scand. J. Infect. Dis. 1992; 24: 577-586.

4. Ulutan F, Kurtar K, Senol E, Sultan N. A foodborne outbreak of group A streptococcal pharyngitis. Mikrobiol. Bult. 1989; 23: 302-311.

5. Ryder RW, Lawrence DN, Nitzkin JL, Feely JC, Merson MH. An evaluation of penicilin during an outbreak of foodborne streptococcal pharyngitis. Am. J. Epidemiol. 1977; 106: 139144.

6. McCormick JB, Hayes P, Feldman R. Epidemic streptococcal sore throat following a community picnic. JAMA 1976; 236: 10391041.

7. Cohen D, Ferne M, Rouach T, BergnerRabinowitzs S. Food-borne outbreak of group $G$ streptococcal sore throat in an Israeli Military Base. Epidemiol. Infect. 1987; 99: 249255.

8. Hill HR, Caldwell GG, Wilson E, Hager D, Zimmermen R. Epidemic of pharyngitis due to streptococci of Lancefield group G. Lancet 1969; $2: 371-374$

9. Strayker WS, Fraser DW, Facklam RR. Foodborne outbreak of group $G$ streptococcal pharyngitis. Am. J. Epidemiol. 1992; 116: $533-$ 540.

10. Bert F, Branger C, Zechovsky NL. Pulsed-Field Gel Electrophoresis is more discriminating than multilocus enzyme electrophoresis and random amplified polymorphic DNA analysis for typing pyogenic streptococci. Curr. Microbiol. 1997; 34: 226-229.

11. Tenover FC, Arbeit RD, Goering RV, Mickelsen PA, Murray BE, Persing DH, Swaminathan B. Interpreting chromosomal DNA restriction patterns produced by pulsed field gel electrophoresis criteria for bacterial strain typing. J. Clin. Microbiol. 1995; 33: 2233-2239. 
